\title{
17. DINOFLAGELLATES AND OTHER PALYNOMORPHS IN SELECTED SAMPLES FROM LEG 14, DEEP SEA DRILLING PROJECT
}

\author{
Daniel Habib, Queens College, Flushing, New York
}

Twenty-four samples representing seven of the sites cored during Leg 14 were macerated for the study of dinoflagellate cysts and other palynomorphs (Table 1). Of these, seventeen contain stratigraphically useful assemblages. Most of the samples were taken from cores collected in the eastern North Atlantic at Site 137, west of Cap Blanc, West Africa ( $25^{\circ} 55.53^{\prime} \mathrm{N} ., 27^{\circ} 03.64^{\prime} \mathrm{W}$.) and in the western North Atlantic at Site 144, north of Surinam, South America ( $09^{\circ} 27.23^{\prime}$ N., $54^{\circ} 20.52^{\prime}$ W. $)$.

This report is preliminary in nature. Many of the samples contain numerous, well-preserved, dinoflagellate cysts, acritarchs, and dispersed land-plant spores and pollen grains (sporomorphs). However, the data presented below list only those taxa which were used for the initial age determintions. A more thorough examination of each assemblage may reveal additional stratigraphically important species, and may permit a more precise age determination.

Age determinations are based on dinoflagellates and acritarchs for the most part; the species are listed below. The distribution of sporomorphs is given as complementary evidence to that of the dinoflagellates. Galeacornead palynomorphs, for example Elaterosporites, are considered stratigraphically important for dating samples from Site 144. In many instances the dinoflagellate assemblages correspond closely to those assemblages recovered at Sites 99, 101 and 105 in the western North Atlantic during Leg 11 (Hollister and Ewing and others, 1972).

The preparation of this report was assisted by a grant from the National Science Foundation (GA-19943).

\section{TABLE 1}

List of Samples From Leg 14

(Numbers marked with an asterisk represent samples in which stratigraphically useful fossils were not found.)

\begin{tabular}{l|l}
$* 135-7-4,51-54 \mathrm{~cm}$. & $* 138-3-1,135-137 \mathrm{~cm}$. \\
$135-9-2,91-93 \mathrm{~cm}$. & $* 140 \mathrm{~A}-2-5,124-126 \mathrm{~cm}$. \\
$* 136-6-1,127-129 \mathrm{~cm}$. & $* 141-8-2,76-78 \mathrm{~cm}$. \\
$136-8-5,3-5 \mathrm{~cm}$. & $144-3-2,110-112 \mathrm{~cm}$. \\
$* 137-3-1,30-33 \mathrm{~cm}$. & $144-4-2,23-25 \mathrm{~cm}$. \\
$137-7-1,1-3 \mathrm{~cm}$. & $144-5-1,95-97 \mathrm{~cm}$. \\
$137-8-1,30-33 \mathrm{~cm}$. & $144-6-1,130-132 \mathrm{~cm}$. \\
$137-11-1,90-92 \mathrm{~cm}$. & $144-7-1,98-100 \mathrm{~cm}$. \\
$137-12-6,121-123 \mathrm{~cm}$. & $144-8-2,119-121 \mathrm{~cm}$. \\
$137-14-2,15-17 \mathrm{~cm}$. & $* 144 \mathrm{~A}-4-2,79-81 \mathrm{~cm}$. \\
$137-15-2,1-3 \mathrm{~cm}$. & $144 \mathrm{~A}-5-1,134-136 \mathrm{~cm}$. \\
$137-16-4,77-79 \mathrm{~cm}$. & $144 \mathrm{~A}-6-1,105-106 \mathrm{~cm}$. \\
\hline
\end{tabular}

\section{Site 135}

Sample 135-9-2, 91-93 cm:

Druggidium (=Microdinium pro parte) deflandrei (Millioud)

Dingodinium cerviculum Cookson and Eisenack

Wallodinium krutzschi (Alberti)

Cribroperidinium muderongensis (Cookson and Eisenack)
Suggested age: Aptian/Albian.

Sporomorphs predominate over dinoflagellates, and include Cicatricosisporites, Appendicisporites, Cyathidites, Ephedripites, Classopollis, Eucommiidites, Ginkgocycadophytus, Tsugaepollenites, Vitreisporites, Taurocusporites, Alisporites, and Abietineaepollenites. The apparent lack of dicotyledonous pollen grains in the otherwise fossiliferous assemblage suggests it is not younger than early Albian.

\section{Site 136}

Sample 136-8-5, 3-5 cm:

Druggidium (=Microdinium pro parte) deflandrei (Millioud) Dingodinium cerviculum Cookson and Eisenack

Chlamydophorella nyei Cookson and Eisenack

Scriniodinium attadalense Cookson and Eisenack)

Suggested age: Aptian/Albian.

The assemblage in this sample closely resembles that in Sample 135-9-2, 91-93 cm.

Site 137

Samples 137-7-1, 1-3 cm:

137-8-1, 30-33 cm:

137-11-1, 90-92 cm:

$137-12-6,121-123 \mathrm{~cm}$ :

137-14-2, 15-17 cm:

137-15-2, 1-3 cm:

Deflandrea acuminata Cookson and Eisenack

Deflandrea? suspecta (Manum and Cookson)

Litosphaeridium siphoniphorum (Cookson and Eisenack)

Ovoidinium scabrosum (Cookson and Hughes)

Odontochitina operculata (Wetzel)

Spiniferites cingulatus (Wetzel)

Cleistosphaeridium ancoriferum (Cookson and Eisenack)

Suggested age: Cenomanian.

The palynomorph assemblages in the above samples closely resemble those found in Cores 9 and 10 at Site 105 in the western North Atlantic (Habib, 1972). Oblate triporate angiospermous pollen grains, for example $\mathrm{cf}$. Complexiopollis, occur in Sample 137-8-1, 30-33 cm., as they do also in Core 9 at Site 105.

Sample 137-16-4, 77-79 cm:

Hexagonifera chlamydata Cookson and Eisenack

Suggested age: Albian/Senonian

This sample is poorly fossiliferous, although the presence of $H$. chlamydata suggests that it is not older than Albian.

Site 144

Sample 144-3-2, 110-112 cm:

Dinogymnium microgranulosum Clarke and Verdier 
Suggested age: Senonian

Sample 144-4-2, 23-25 cm:

Palaeohystrichophora infusorioides Deflandre Deflandrea acuminata Cookson and Eisenack Deflandrea? suspecta (Manum and Cookson)

Suggested age: Cenomanian/Turonian.

Sample 144-5-1, 95-97 cm:

Deflandrea echinoidea Cookson and Eisenack

Suggested age: Cenomanian/Albian.

Elaterosporites verrucatus (Jardiné and Magloire) and $E$.

klaszi (Jardiné and Magloire), palynomorphs of uncertain botanical affinity, occur in the sample listed above. These species are restricted to Albian-Cenomanian (?Turonian) sediments in Senegal, Ivory Coast, Nigeria, Gabon, Algeria, and in the Maranhão Basin of Brazil (Jardiné, 1967). Palynomorphs of this type have been reported from the Middle Cretaceous of Portuguese Guinea (Stover, 1963) and the Horizon A area (Habib, 1969).

Samples 144-6-1, 130-132 cm:

144-7-1, 98-100 cm:

144-8-2, 119-121 cm:

Druggidium (=Microdinium pro parte) deflandrei (Millioud)

Chlamydopohorella nyei Cookson and Eisenack

Coronifera oceanica Cookson and Eisenack

Palaeohystrichophora infusorioides Deflandre
Suggested age: Albian.

Elaterosporites verrucatus is present in the three samples listed above; this supports the age being not older than Albian. Prolate tricolpate dicotyledonous pollen grains are present in Sample 144-7-1, 98-100 cm, which also supports this conclusion.

Samples 144A-5-1, 134-136 cm:

144A-6-1, 105-106 cm:

cf. Baltisphaeridium armatum (Deflandre)

Suggested age: Probably Cenomanian/Senonian.

\section{REFERENCES}

Habib, D., 1969. Middle Cretaceous palynomorphs in a deep-sea core from the seismic reflector Horizon A outcrop area. Micropaleontology. 15 (1), 85.

1972. Dinoflagellate stratigraphy, Leg 11, Deep Sea Drilling Project. In Hollister, C. D. and Ewing, J. I. and others, 1972. Initial Reports of the Deep Sea Drilling Project, Volume XI. Washington (U.S. Government Printing Office), in press.

Hollister, C. D., Ewing, J. I., and others, 1972. Initial Reports of the Deep Sea Drilling Project, Volume XI. Washington (U.S. Government Printing Office), in press.

Jardiné, S., 1967. Spores à expansions en forme d'élatères du crétacé moyen d'Afrique occidentale. Rev. Palaeobotan. Palynol. 1, 235.

Stover, L. E., 1963. Some Middle Cretaceous palynomorphs from West Africa. Micropaleontology, 9 (1), 85. 

PLATE 1

Magnification approximately $\times 870$

Figure $1 \quad$ Elaterosporites verrucatus (Jardiné and Magloire).

1a. Focus on lateral prongs.

1b. Focus on central body and axial prong. Sample $144-8-2,119-121 \mathrm{~cm}$.

Figures 2, 3 Druggidium deflandrei (Millioud).

2a. Note precingular archeopyle, with two opercular pieces adhęring at the cingulum. Epitract is otherwise intact, as can be seen by the continuous line across the apex. 2b. Ventral surface. Note small but discrete apical plates and characteristically square fifth and sixth plates of the cingular series. The spatulate sulcus lies adjacent the triangular first postcingular plate.

Sample 136-8-5, 3-5 cm.

3a. Tabulation of dorsal hypotract. 3b. Opercular pieces in focus. 3c. Tabulation of ventral surface. Note spatulate sulcus with anterior sulcal platelet, rectangular posterior intercalary plate, and triangular first postcingular plate.

Sample 136-8-5, $3-5 \mathrm{~cm}$. 


\section{PLATE 1}
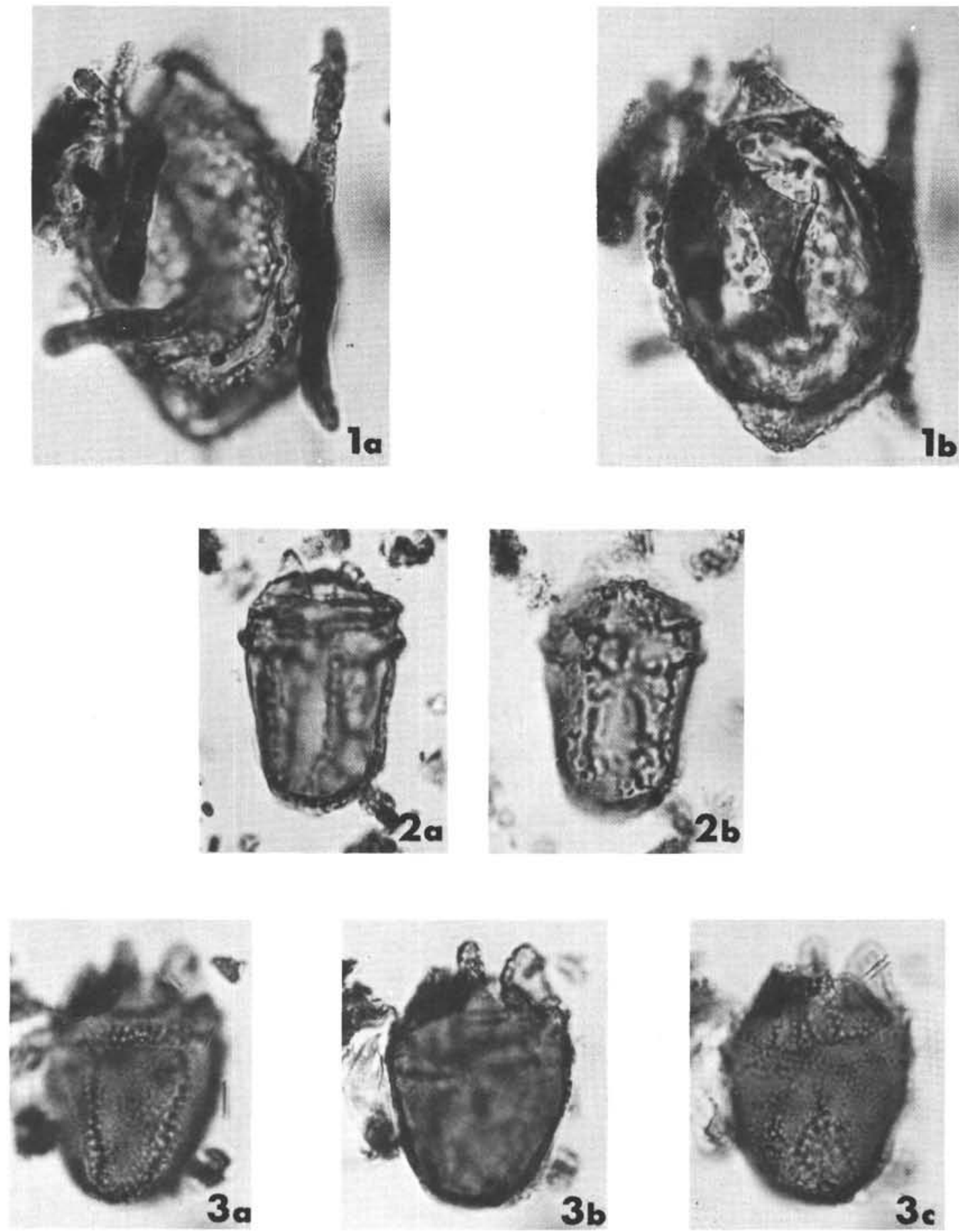